https://doi.org/10.15407/ufm.21.04.481

\author{
G.P. STOVPCHENKO ${ }^{1,2, *}$, A.V. SYBIR ${ }^{2,3}$, \\ G.O. POLISHKO ', L.B. MEDOVAR ${ }^{1,2, * *}$, and Ya.V. GUSIEV ${ }^{1}$ \\ 'E.O. Paton Electric Welding Institute of the N.A.S. of Ukraine, \\ 11 Kazimir Malevich Str., UA-03150 Kyiv, Ukraine \\ ${ }^{2}$ Private Engineering Company 'ELMET-ROLL', Post Office Box 259, \\ UA-03150 Kyiv, Ukraine \\ ${ }^{3}$ National Metallurgical Academy of Ukraine, 4 Gagarin Ave., \\ UA-49600 Dnipro, Ukraine \\ *anna_stovpchenko@ukr.net,office@elmet-roll.com.ua, **medovar@ukr.net
}

\title{
MASS TRANSFER IN ELECTROSLAG PROCESSES WITH CONSUMABLE ELECTRODE AND LIQUID METAL
}

Experimental and numerical comparisons of mass transfer processes during the electroslag remelting with consumable electrode (ESR) and electroslag refining with liquid metal (ESR LM) showed their identical refining capacity, despite the smaller both the slag-metal contact surface (twice) and metal overheat (by 70-95 K) in the latter case. As revealed, due to effect of metal movement inside the liquid metal drop, it moves in liquid slag faster than a solid particle of the same diameter. Under comparable conditions, it is experimentally confirmed that desulphurization at the ESR takes place mainly on the contact surface between the slag and metal baths, but not in the liquid metal film at the tip of a consumable electrode.

Keywords: electroslag remelting with consumable electrode, similarity criteria, turbulence, stream, desulphurization.

\section{Introduction}

The industry's demand for high-grade steels and alloys is constantly growing. Nowadays such steels and alloys are mostly produced by special electrometallurgy technologies, of which the most common is electroslag remelting (ESR). A scheme for standard ESR in presented in Fig. 1, a. ESR involves the use of consumable electrodes, which melts

Citation: G.P. Stovpchenko, A.V. Sybir, G.O. Polishko, L.B. Medovar, and Ya.V. Gusiev, Mass Transfer in Electroslag Processes with Consumable Electrode and Liquid Metal, Progress in Physics of Metals, 21, No. 4: 481-498 (2020) 


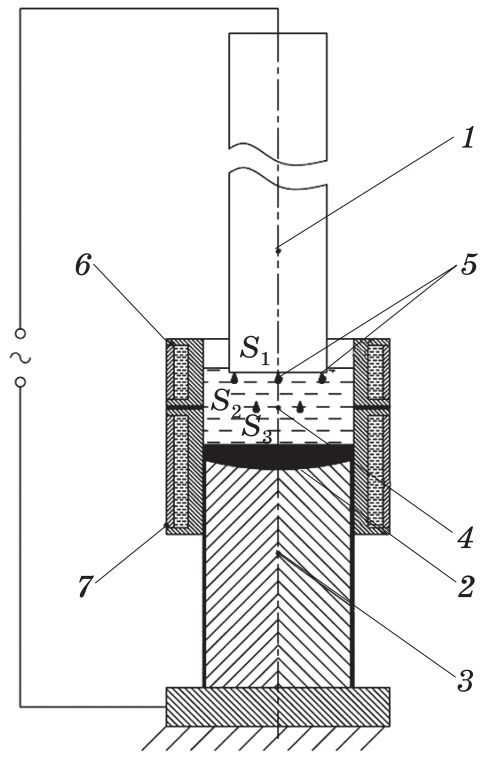

$a$

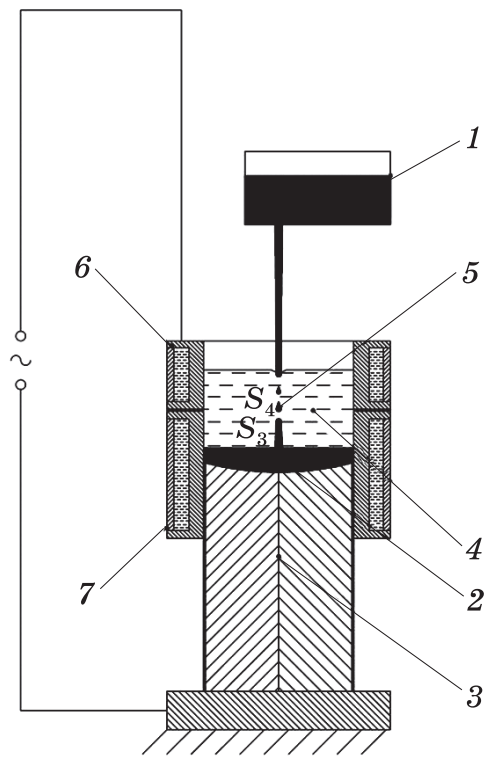

$b$

Fig. 1. ESR with consumable electrode $(a)$ and liquid metal $(b): 1$ - consumable electrode $(a)$ and a device for pouring metal $(b), 2$ - bath of liquid metal, 3 - ingot, 4 - liquid slag, 5 - drops of liquid metal from the consumable electrode $(a)$ and stream of liquid metal $(b), 6,7$ - sections of the water-cooled mould. $S_{1}-S_{4}-$ the interaction surface of the liquid metal with slag

at relatively low speed under a slag layer. A special kind of rain from metal drops creates a bath of liquid metal, which solidifies again in the water-cooled mould and forms an ingot. The ESR ingot is very solid and homogeneous along the cross section and height [1,2].

The ingot formation rate in the ESR process is much smaller in comparison with processes of liquid metal casting into ingots or into a continuously cast billet by traditional metallurgy. An intentional significant reduction in the potential productivity of the melting process for the sake of high product quality is a typical characteristic of all remelting processes. The purpose is to minimize the volume of the liquid metal bath aiming to prevent the segregation of the elements and the formation of shrinkage cavities. Just the understanding that the stable and high quality of metal products require homogeneous composition and structure of the metal has led to a recent boom in development of additive manufacturing technologies, of which the ideology involves the layer-by-layer formation of products. This is necessary for the freedom in forming (so-called $3 D$ printing) and ensuring of uniform and reproducible composition of the product, which is possible only by minimizing the liquid metal bath. We emphasize that majority of the modern additive production processes are the remelting ones $[3,4]$ because 
solid blanks of pre-obtained chemical composition are used (wires, powders, etc.). In other words, all the technologies of special electrometallurgy, namely, vacuum arc, electroslag, plasma arc and electron beam remeltings, are additive. The comprehension of this and the necessity of a more deep understanding of remelting processes nature (ESR in our case), has been a key for this research.

\section{State of the Problem and Research Objectives}

In addition to the standard ESR with consumable electrodes, the electroslag technology with the use of liquid metal instead of consumable electrodes, ESR LM, has been developed in recent years, which is schematically shown in Fig. 1, $b$. For its implementation, a sectional mould is used to bring the current to the slag through the upper section, which acts as a non-consumable electrode [5-7].

It is already proven within an extensive program of laboratory experiments and industrial tests that the replacement of consumable electrodes by liquid metal opens wide opportunities for improving the homogeneity of the ingot and the flexibility of technological process [8-13]. It concerns particularly the production of alloys, which have a large amount of alloying elements and are difficult to be deformed.

At the same time, the increased application of new technologies and equipment instead of the standard ESR with consumable electrodes requires a theoretical and experimental study of involved processes and the evaluation of quality of ingots, as well as the effectiveness of their production. Even more, some details of mass transfer processes during standard ESR are not fully investigated, in particular, with respect to the surface where predominantly the refining takes place. Even today, many researchers support an idea about the main role of interaction between liquid metal in the film at the end of the consumable electrode and liquid slag in the refining process, as well as in metal desulphurization during the ESR [14-16]. At the same time, B.I. Medovar and his school did not sustain this idea and considered that the refining processes take place on all the surfaces of metal-slag interaction and the main role is played by the interaction of liquid metal with slag at the interface of their baths in the melt ingot. [1, 2, 13]. For this reason, we made a comparative analysis of these types of ESR - the standard one with a consumable electrode and that with a liquid metal to solve this fundamental question.

Marks $S_{1}$ to $S_{4}$ in Fig. 1 relate to the reaction surfaces of metal and slag. To make similar the conditions of comparative experiments ESR with a consumable electrode and a liquid metal, they were performed in the same sectional mould with the same amount of slag. However, in the experiments with a consumable electrode, the current was supplied only to the electrode. The ingot remelting rate was kept the same. 
For standard ESR, the contact surface area of the liquid metal film at the end of the consumable electrode, which melts in the slag bath, is marked as $S_{1}$, whereas the surface area of the drop of a unique rain of liquid metal contacting with the layer of slag is denoted as $S_{2}$. Be the same in the both types of ESR, the area of contact surface between the baths of liquid slag and metal is marked as $S_{3}$. The area $S_{4}$ is related to a stream of liquid metal in the ESR LM process.

Let us analyse in this way conditions of the mass transfer in the course of interaction between metal and slag in the both processes of ESR at the same chemical composition and evaluate distinctions related with the substitution of melting of consumable electrode for the liquid metal.

It is known that these processes differ in temperatures of the slag and metal because the traditional ESR requires significant overheating of the slag for melting the consumable electrode. It is impossible to significantly reduce the overheating of the slag bath during the ESR with a consumable electrode because, for some physical features of contact heating during passage of an electric current, a decrease in slag temperature leads to the loss of process productivity up to cessation of electrode melting.

Usually, the temperature of the slag bath during the ESR with consumable electrode is estimated to be of 100 to $250 \mathrm{~K}$ higher than the liquidus temperature of steel. The overheating of metal drops in the slag is considered as 90 to $100 \mathrm{~K}$ above this temperature [7]. In our comparative experiments, the specific power consumption of ESR with consumable electrode was on the average of $1350 \mathrm{kWh} /$ ton of ingot, and only $900 \mathrm{kWh} /$ ton for the ESR LM. In other words, at equivalent processing rates, the total heat input to the system is smaller in the latter case.

At the same time, the experience of continuous casting, where the ingot is also produced in the water-cooled mould, shows that it is sufficient to maintain overheating not higher than 10 to $30 \mathrm{~K}$ in order to form a high-quality surface of the ingot, and this temperature margin is sufficient to pour a large-tonnage ladle. In the ESR LM, the metal from the heating pouring device can be fed with a minimum overheating of 0 to $15 \mathrm{~K}$ above the liquidus temperature and in some cases even below it. It is clear that the slag temperature during the ESR LM will be also lower, which increases stability of its properties and reduces its electrical conductivity. A smaller electrical conductivity of the slag leads to additional savings in the electricity consumption, although it is rather small.

In other words, taking into account the physical and chemical conditions it is possible that interactions during ESR LM occur at temperatures lower by 70 to $95 \mathrm{~K}$. However, this should not significantly affect the reaction of metal desulphurization despite some increase in slag viscosity, which may hypothetically affect assimilation of non-metallic 
inclusions. The undoubted advantages of lower temperatures of metal fed during the ESR LM and of the slag are the better conditions for solidification of the ingot.

In addition to different temperatures, there is also difference in the development of the slag-metal interaction surfaces. The contact surface between the baths of liquid metal and slag, $S_{3}$, is the same for ESR and ESR LM, and its area is close to that of horizontal cross section of the ingot. Physical and chemical interactions on this surface occur throughout all the time of existing liquid metal baths in the both technologies. The contacting slag bath has a high temperature, although non-uniform along its height, as well as the turbulence, which is initiated by electromagnetic fields during passage of a powerful electric current, by the falling drops from the electrode or by the stream of liquid metal.

In contrast to classical ESR process with an electrode, the first above-mentioned surfaces $S_{1}$ and $S_{2}$ are absent during the ESR LM, see Fig. 1, $b$, because there is no consumable electrode and the liquid metal is fed to the molten slag as a stream. The diameter of this stream and its granulation into the drops depend on the specific flow rate of liquid metal, which is fed by portions or continuously and on the height from which the stream falls. The liquid metal stream can open and break into drops due to the forces of inertia and viscous friction with the slag or surface tension, counter flow of slag etc. In any case, it is likely that the size of the formed drops does not exceed the diameter of stream. The total surface area of the stream and drops at the ESR LM is indicated as $S_{4}$ in Fig. $1, b$.

According to the data from many sources [1, 2, 7, 17-21], because of the inherent high electric resistance and low thermal conductivity of slag, its highest temperature during the ESR with consumable electrode, from 1900 to $2200 \mathrm{~K}$, occurs in the place of contact with an electrode. The film of molten metal at the end of the electrode $\left(S_{1}\right)$ is formed just due to contact with the overheated layer of slag. In modern ESR processes, the electrode surface (filling ratio) is of about 0.6 to 0.7 of the ingot one, so that the surface of the film is the same. Its thickness is of 0.08 to $0.52 \mathrm{~mm}$ in accordance with our experimental data and results of measurements and calculations performed by other researchers $[2,21,22]$.

The size of drops depends on the diameter of the electrode and is directly proportional to it, whereas the current density is inversely proportional and is of 1 to $10 \mathrm{~mm}$, according to [23,24]. The same values were obtained by the authors of [25] based on the results of numerical simulations, where the equivalent drops diameter was of $10 \mathrm{~mm}$ to15 $\mathrm{mm}$ for the largest drops and 1 to $4 \mathrm{~mm}$ for the smallest ones.

During the ESR LM, the stream of liquid metal, $S_{4}$, also passes through the slag bath and the interactions on the slag-metal surface, 
$\mathrm{S}_{3}$, occur all the time of the contact (Fig. 1). In a simplest case, if the stream is not broken into drops, the interaction surface can be expressed as the surface of a cylinder having the stream diameter and the length that matches with the mass of the metal at given productiveness.

The absence of one of the interaction surfaces (film at the end of the electrode) and other type of metal transfer through the slag can affect the refining capacity during the ESR LM. The assessment of drop transfer needs the taking into account a size of drops and time of their movement in the slag melt within the frame of a corresponding physicalchemical model.

\section{Parameters for Motion of a Metal Drop at ESR}

The motion parameters of small particles (drops) in liquid fluid and their thermal interaction with this fluid are important in many metallurgical, thermal and chemical processes. A significant number of studies is devoted to this subject, e.g., Refs. [26-29]. In relation to metallurgical processes, the analysis is usually performed for motion of metal particles into the slag or slag particles into the metal during the production or refining of metal alloys [30,31]. The motion of gas bubbles in metal or slag is also frequently investigated $[32,33]$. The most important parameter in studies of the liquid particles dynamics is the resistance factor. Quite often, the resistance factor is determined either by Stokes' law for motion at small Reynolds numbers or by the more complex dependences, which take into account a change in the nature of the flow around the sphere with increasing Reynolds criterion [34].

It should be emphasized that in most cases it is assumed that the investigated particle of liquid metal is a solid sphere. However, the motion of a liquid particle has a feature of a smaller resistance due to the lower friction forces on the particle surface. This feature is properly studied for the conditions of gas bubbles motion. The motion of gas bubbles or liquid drops in the liquid are quite similar in their physical essence, which allows the usage of regularities resulting from experiments in a criterion form. Numerical methods are also used to study the motion of drops, which makes it possible to investigate the velocity fields outside and inside the drop [35]. However, these methods are quite difficult for calculations.

The estimation of drop size formed during remelting the consumable electrode is in detail described in many works, e.g. in Refs. [2, 7]. At the same time, the assessment of the nature of drop motion through the slag is usually carried out according to Stokes' law, which in our opinion should be clarified more precisely. A scheme of drop motion in the slag bath presented in Fig. 2 has been used for calculations, where $d$ is drop diameter, $F_{G}$ is gravity force, $F_{A}$ is Archimedes' force, $F_{D}$ is motion 


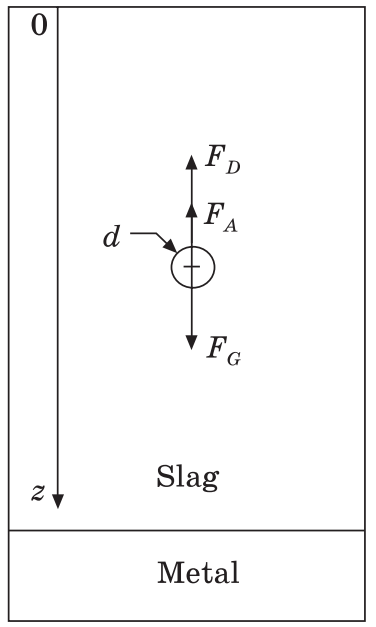

$a$

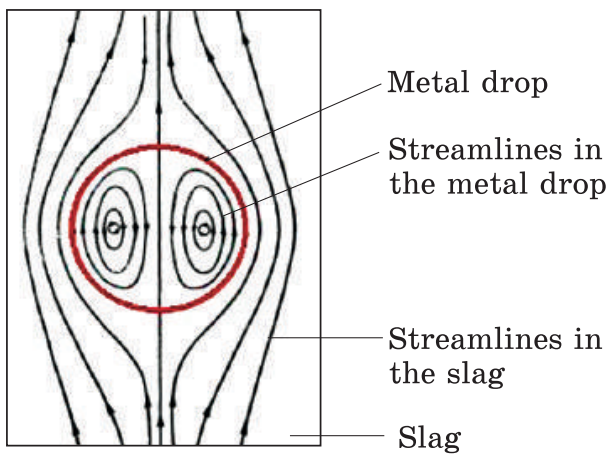

$\int \begin{aligned} & \text { Metal drop } \\ & \text { direction }\end{aligned}$

$b$

Fig. 2. The scheme of forces (a) acting on a liquid drop of metal with diameter $d$, which falls into the metal from the electrode (ESR) or occurs when the stream is crushed (ESR LM), and the nature of the motion in its volume (b) [25]

resistance force for the drop in the slag. Main quantitative properties of the slag and metal used in this simulation are listed in Table 1.

As assumed in the simulation, a metal drop passing through the slag is heated to a temperature close that of the molten slag and it can be divided into smaller drops. The difference in the falling distance of the drops at the ESR and of the stream at the ESR LM is negligible. A reason for that, in up-to-date melting modes, the immersion depth of the consumable electrode is minimal and it can be assumed that the electrode is located on the surface of the slag bath. The slag bath height was taken to be of $200 \mathrm{~mm}$ in calculations. The motion of metal drops of different diameters in the molten slag was estimated taking into account its viscosity and using hydrodynamics methods of multiphase medium [36-39]. Calculations describing the motion of a metal drop in

Table 1. Thermophysical properties of slag and metal in modelling the heating of drops

\begin{tabular}{|l|c|c|}
\hline \multicolumn{1}{|c|}{ Property } & Slag ANF-29 & Metal (steel 45) \\
\hline Viscosity $\mu, \mathrm{Pa} \cdot \mathrm{s}$ & temperature & $5 \cdot 10^{-3}$ \\
& dependent variable & 7000 \\
Density $\rho, \mathrm{kg} / \mathrm{m}^{3}$ & 2780 & 700 \\
Heat capacity $C, \mathrm{~J} / \mathrm{kg} \cdot \mathrm{K})$ & 1250 & 35 \\
Thermal conductivity $\lambda, \mathrm{W} /(\mathrm{m} \cdot \mathrm{K})$ & $3.2-3.5$ & \\
\hline
\end{tabular}


the melt slag were carried out using criterial numbers of Archimedes $(A r)$, Reynolds $(R e)$, and Nusselt $(N u)$ :

$$
A r=\frac{\rho_{S}\left(\rho_{M}-\rho_{S}\right) g d^{3}}{\mu_{S}^{2}}, R e=\frac{\rho_{S} U d}{\mu_{S}}, N u=\frac{\alpha d}{\lambda_{S}},
$$

where $\rho_{S}$ and $\rho_{M}$ are densities of slag and metal, respectively, in $\mathrm{kg} / \mathrm{m}^{3}$; $\mu_{s}$ is dynamic viscosity of the slag, $\mathrm{Pa} \cdot \mathrm{s} ; d$ is drop diameter, $\mathrm{m} ; U$ is drop motion speed, $\mathrm{m} / \mathrm{s} ; \alpha$ is heat transition coefficient, $\mathrm{W} /\left(\mathrm{m}^{2} \cdot \mathrm{K}\right) ; \lambda_{S}$ is thermal conductivity of the slag, $\mathrm{W} /(\mathrm{m} \cdot \mathrm{K}) ; \mathrm{g}$ is gravitational acceleration, $\mathrm{m} / \mathrm{s}^{2}$.

It is known that if a liquid drop moves in other liquid, three flow regimes can be operative [40]: according to Stokes (a viscous flow) with $R e<1$, transient regime at $1<R e<1000$ and according to Newton with quadratic law of resistance and $R e>1000$. The equation binding the forces acting on a drop in a liquid during its stationary motion (gravity, Archimedes force and viscosity force) has the following dimensionless form [40]:

$$
C_{D} R e^{2}=\frac{4}{3} A r
$$

where $C_{D}$ is resistance factor of the motion, which depends on the flow regime. For the case of movement of a liquid drop in a liquid, the coefficient $C_{D}$ is determined as

$$
\begin{gathered}
C_{D}=\frac{24}{R e} \frac{2+3 \mu^{*}}{3+3 \mu^{*}}, \quad R e<1, \\
C_{D}=\frac{C_{D 0}(R e)+\mu^{*} C_{D \infty}(R e)}{1+\mu^{*}}, \quad 1<R e<5000, \\
C_{D}=0.44, \quad 5000<R e,
\end{gathered}
$$

where $C_{D 0}=17.325 R e^{-0.947}+0.341$ is resistance for gas bubble; $C_{D 0}=$ $=24 / R e+4 / \sqrt[3]{R e}$ is that for hard sphere; $\mu^{*}=\mu_{M} / \mu_{S}$ is the ratio of dynamic viscosities of metal and slag. For the considered case, $\mu^{*} \in(0.01 ; 0.5)$.

Based on the value of the Archimedes criterion, one can find the diameter of the drop at which the flow ceases to be viscous. For our initial data, this diameter $d=2.9 \mathrm{~mm}$ at slag viscosity of $0.5 \mathrm{~Pa} \cdot \mathrm{s}$ and $d=0.29 \mathrm{~mm}$ at $0.01 \mathrm{~Pa} \cdot \mathrm{s}$. Therefore, the movement of a metal drop in the melt slag should occur in the transient regime. In our case of motion of a liquid drop in a liquid under the action of gravity, due to smaller shear stresses at the liquid-liquid surface, its velocity will be higher than that of a solid sphere having similar diameter. This is possible due to the circulation inside the drop (see Fig. $3, b$ ).

A second important point is the non-stationarity of the motion process because the initial velocity of the drop is zero and, e.g. for drops of 




Fig. 3. The values of the contact surfaces of slag and metal in ESR and ESR LM, which are expressed in parts of the metal bath surface

rather large in diameter, a steady state velocity determined by Eq. (1) will be only reached when it leaves the slag. Therefore, for calculation of drop motion time, it is necessary to solve the following equation:

$$
\frac{d U}{d \tau}=g \frac{\left(\rho_{M}-\rho_{S}\right)}{\rho_{M}}-\frac{3 \rho_{S} C_{D}(R e)}{4 d \rho_{M}} U^{2} .
$$

This differential equation cannot be solved analytically due to a complex dependence of $C_{D}$ on the velocity $U$. For this reason, a numerical method is used to solve it; the obtained solution looks like $U=f(\tau)$. Similarly, to obtain the time of drop motion through the slag layer of $H$ in the height, the following equation is needed:

$$
\int_{0}^{\tau_{\kappa}} U(\tau) d \tau-H=0
$$

which was also solved numerically.

After determining the motion time and speed, one can estimate the dimensionless temperature $\theta=\left(t_{S}-t_{M}\right) /\left(t_{S}-t_{M}^{0}\right)$, which is acquired by drop in the slag. Its limiting values are $\theta=1$ in case if the drop is not heated, and $\theta=0$ when the drop reaches the slag temperature. This temperature has been calculated for a thermally slender body in accordance with the well-known formula

$$
\theta=\exp \left(-\frac{3 \alpha \tau}{C_{M} \rho_{M} d}\right)
$$


For estimation of the heat transition coefficient, the Nusselt criterion was calculated using the formula [41]:

$$
\mathrm{Nu}=2.0+0.6 \mathrm{Re}^{1 / 2} \mathrm{Pr}^{1 / 3},
$$

where $\operatorname{Pr}=C_{p} \mu / k\left(C_{p}\right.$ is a heat capacity of air at constant pressure, $\mu$ and $k$ are the dynamic viscosity and thermal conductivity of air, respectively) is the Prandtl number.

Two calculations were made to estimate a divergence between the calculations of passage time of the drop through slag layer according to the used model or to the Stokes' law. Presented in percentage, the time difference between the motion of the drop according to Stokes' law and to the used model was marked as $\Delta$. The obtained result confirms a significance of the performed above clarification, which took into account the effect of metal motion inside the drop compared to the results of calculations using the Stokes' law (see Table 2).

Under selected conditions and thermophysical parameters of materials which were specified in this calculation for the ESR processes, a drop of liquid metal having, e.g., $9 \mathrm{~mm}$ in diameter moves in the liquid slag by $26 \%$ faster than a solid sphere of the same diameter. The calculated values of the Reynolds criterion for drops with a diameter of 2 to $6 \mathrm{~mm}$ show a transient flow regime, i.e. the unstable turbulence where the flow can be both turbulent and laminar. For larger drops with $R e>1000$ the flow regime is turbulent, which affects the heat transfer.

The values of the Nusselt criterion also increase with increasing of the drop diameter, which testifies an increase in heat transfer intensity due to convection in the motionless media. Only for drops with a diameter of 2 and $3 \mathrm{~mm}$, the calculated Nusselt criterion, from 2 to 20, is in the range typical for the laminar flow and for larger diameters of drops, which evidences a strong convective constituent of heat stream and is typical for turbulent flows.

Table 2. Regimes of motion and heating of drops of different diameter (mass) in a layer of slag $0.2 \mathrm{~m}$ high

\begin{tabular}{|c|c|c|c|c|c|r|}
\hline $\begin{array}{c}\text { Diameter, } \\
\text { mm (Mass, mg) }\end{array}$ & Velocity, m/s & Time, s & $\theta$ & $R e$ & $N u$ & $\Delta, \%$ \\
\hline $2(29.3)$ & 0.246 & 0.841 & 0.003 & 136.3 & 13.2 & 3.6 \\
$3(98.9)$ & 0.341 & 0.627 & 0.067 & 282.6 & 18.1 & 6.8 \\
$4(234)$ & 0.421 & 0.526 & 0.202 & 464.3 & 22.6 & 10.3 \\
$5(458)$ & 0.475 & 0.477 & 0.337 & 656.9 & 26.6 & 13.2 \\
$6(792)$ & 0.521 & 0.445 & 0.449 & 863.6 & 30.2 & 15.9 \\
$7(1260)$ & 0.562 & 0.422 & 0.537 & 1088 & 33.6 & 18.5 \\
$8(1880)$ & 0.601 & 0.403 & 0.607 & 1330 & 36.9 & 21.1 \\
$9(2670)$ & 0.637 & 0.388 & 0.661 & 1587 & 40.2 & 26.0 \\
$10(3670)$ & 0.672 & 0.376 & 0.705 & 1858 & 43.3 & 26.4 \\
\hline
\end{tabular}


The calculations have shown a significant effect of inherent flows in the large drops on the velocity of their motion in the slag melt, which makes the prediction to be inaccurate, which is usually obtained according to Stokes' law for the motion of solid particles in the liquid. A reason for that is the inherent turbulence of the drop and the related decrease in the resistance to its motion in the liquid slag. Therefore, large drops move relatively faster than drops of small diameter.

In relation to comparable processes, it should be noted that, in the ESR with a consumable electrode, the size of drops is smaller and, accordingly, they move more slowly and are heated to a large extent. This is useful in terms of refining because of higher temperature and more effective surface, but does not favour the ingot solidification.

On the contrary, the relatively large size of drops, into which the stream is split, or their absence create conditions for reducing the interaction with slag. This improves conditions for ingot formation because, as compared to the classical ESR, a decrease in temperature of slag and overheating of the metal in the ESR LM reduces the volume of the liquid metal bath.

Finally, a decision was made to test these formally logical models based on the direct experimental comparison of completion degree for physical-chemical processes under identical conditions.

\section{Evaluation of Interaction Surfaces and Experimental Comparison of Refining Capacity in the ESR and ESR LM}

Using a furnace for standard ESR and ESR LM with downward ingot, as well as a refractory lined crucible furnace for preparation of liquid metal and a flux melting furnace, experimental melts were performed in the laboratory conditions of the E.O. Paton Electric Welding Institute of the National Academy of Sciences of Ukraine. To ensure similar melting conditions and using comparable technologies, they were performed in the same sectional mould of round cross section of $180 \mathrm{~mm}$ in diameter. The productivity of both processes was of $120-160 \mathrm{~kg} / \mathrm{h}$ and withdrawal rate of the ingot was equal to $15-17 \mathrm{~mm} / \mathrm{min}$.

The St45 steel was remelted under ANF-29 slag with layer height of $200 \mathrm{~mm}$ and specific consumption of $28 \mathrm{~kg} /$ ton. For calculated evaluation of interaction surfaces, the mass rate of the feed was chosen to be $160 \mathrm{~kg} / \mathrm{h}(0.044 \mathrm{~kg} / \mathrm{s})$, which is typical for stationary stage of the process.

The size and amount of drops in the ESR were measured and counted directly at the electrode tip of $160 \mathrm{~mm}$ in diameter during its rapid freezing. The obtained number of drops was recalculated into the mass melting rate and their total square as well as their reduced area have been determined (see Table 3), taking into account the resident time of drops in the slag in accordance with Table 2. 


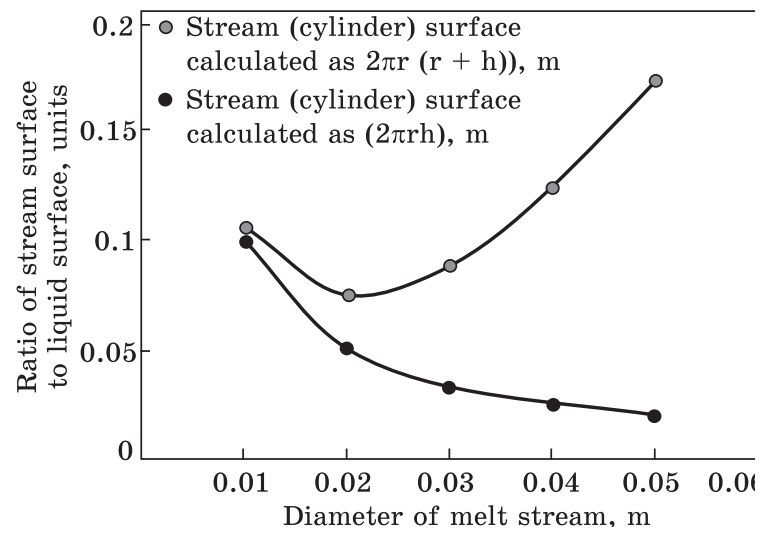

Fig. 4. The stream surface of one mass, expressed as a part of the bath surface at its different diameters

The low productivity does not allow the ESR RM to be poured continuously, so that the metal was poured in portions of 2 to $3 \mathrm{~kg}$. The productivity in formation of a qualitative remelted ingot is always low, and therefore, in most cases, the ESR LM is maintained using partial giving of the metal. For example, even for large ingots of $2000 \mathrm{~mm}$ in diameter, the consumption of liquid metal of 0.4 to $0.6 \mathrm{~kg} / \mathrm{s}$ is used.

Under conditions of our laboratory experiments, the stream of liquid metal had a diameter of 10 to $20 \mathrm{~mm}$ and was partially broken into the drops of smaller size. For calculations of the total surface area, it was assumed that the stream has a diameter of $10 \mathrm{~mm}$ and the drops constituted $15 \%$ of metal mass per second with uniform distribution of their quantity in size of 6 to $9 \mathrm{~mm}$.

Table 3. Characteristics of drops/streams in comparable ESR processes existing in the system for 1 second at the same mass productivity of $0.044 \mathrm{~kg} / \mathrm{s}$

\begin{tabular}{|c|c|c|c|c|c|c|}
\hline Process & $\begin{array}{l}\text { Diam- } \\
\text { eter, } \\
10^{3} \mathrm{~m}\end{array}$ & $\begin{array}{c}\text { Amount } \\
\text { of drops, } \\
\text { pcs. } \\
\text { or stream } \\
\text { length, m }\end{array}$ & $\begin{array}{l}\text { Mass, } \\
\mathrm{kg} \cdot 10^{3}\end{array}$ & $\begin{array}{c}\text { Total } \\
\text { area } \\
\text { surface, } \\
10^{4} \mathrm{~m}^{2}\end{array}$ & $\begin{array}{c}\text { Motion time } \\
\text { of drops/ } \\
\text { stream } \\
\text { in the slag, } \\
\text { sec }\end{array}$ & $\begin{array}{l}\text { The total interaction } \\
\text { surface with taking } \\
\text { into account } \\
\text { the motion time } \\
\text { of the slag, } 10^{4} \mathrm{~m}^{2}\end{array}$ \\
\hline \multirow[t]{5}{*}{ ESR, drops } & 2 & 140 & 4.1 & 17.58 & 0.841 & 14.79 \\
\hline & 3 & 80 & 7.9 & 22.61 & 0.627 & 14.18 \\
\hline & 4 & 60 & 14.0 & 30.14 & 0.526 & 15.86 \\
\hline & 5 & 40 & 18.3 & 31.41 & 0.477 & 14.98 \\
\hline & Total & 320 & 44.3 & 101.74 & & 59.81 \\
\hline $\begin{array}{l}\text { ESR LM } \\
\text { Stream } 0.01 \mathrm{~m} \\
(0.85 \text { of mass })\end{array}$ & 10 & 0.069 & 37.8 & 23.16 & & 23.16 \\
\hline \multirow{5}{*}{$\begin{array}{l}\text { Drops } \\
\quad(0.15 \text { of mass })\end{array}$} & 6 & 1 & 0.79 & 1.13 & 0.445 & 0.503 \\
\hline & 7 & 1 & 1.26 & 1.54 & 0.422 & 0.65 \\
\hline & 8 & 1 & 1.88 & 2.01 & 0.403 & 0.81 \\
\hline & 9 & 1 & 2.67 & 2.54 & 0.388 & 0.99 \\
\hline & Total & & 44.1 & 30.38 & - & 26.11 \\
\hline
\end{tabular}



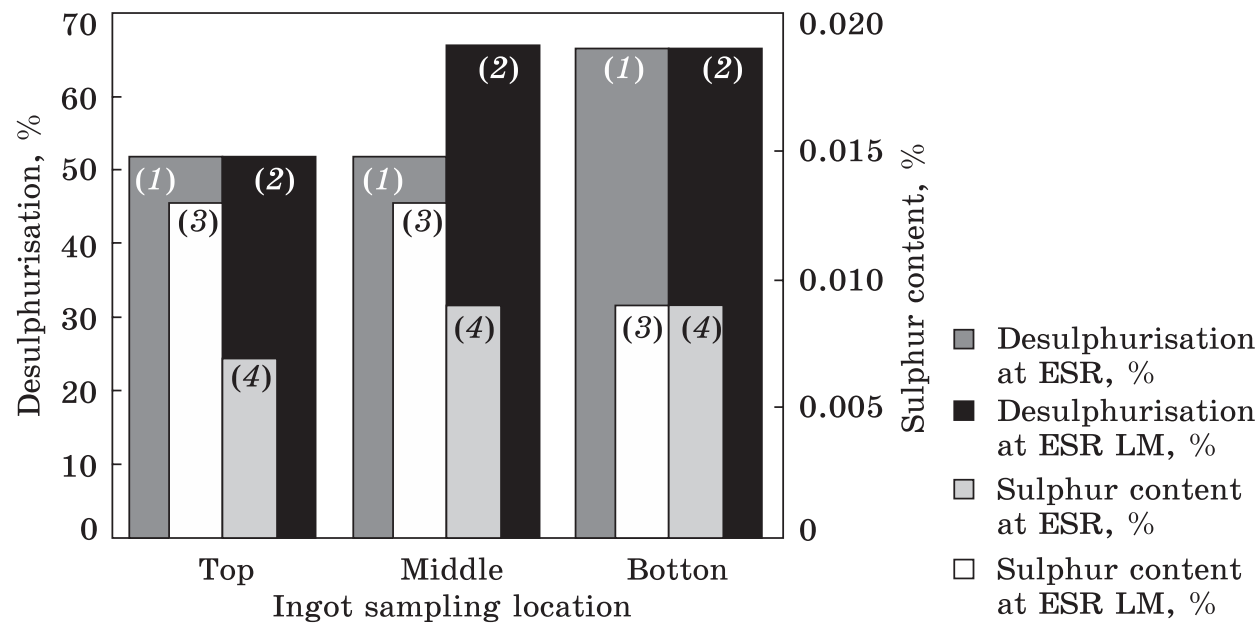

Fig. 5. Sulphur content and the degree of desulfurization in the metal of ingots obtained by ESR and ESR LM under comparable conditions

To compare and visualize the obtained results in relation to interaction surfaces in both processes, their areas were presented as a part of the metal bath surface which was taken as a unit; see Fig. 3.

It is obtained that the total interface of the metal and slag phases in the ESR is twice as large as that in the ESR LM, namely 2.03 against 1.12 here and further in the parts of the surface of the metal bath. As expected, the largest difference, $\mathbf{0 . 7 9}$, is due to the surface of the electrode. Nevertheless, due to the small size of the drops, the part of their surface constitutes 0.23 , if to take into account velocity of their movement in the slag, and 0.4 without that.

For the ESR LM, the total surface is presented for the case of $0.15 \%$ splitting of the stream having $0.01 \mathrm{~m}$ in diameter into large drops. If to take into account the velocity of their motion in the slag, their relatively small contribution is reduced from 0.028 to 0.012 .

It is remarkable that, with increasing stream diameter, its surface also increases, if to calculate it as a total surface of the cylinder and its part becomes more noticeable (Fig. 4). Therefore, in case of necessity to increase the contact surface of the liquid metal with the slag at the ESR LM, one can increase the stream diameter or arrange the stream dispersion, which, e.g., can be done by a counter supply of the inert gas.

As soon as the refining ability of the electroslag processes ESR and ESR LM becomes mainly apparent as the removal of sulphur, it is possible to compare it by measuring the sulphur content in the metal before and after remelting using standard methods.

The consumable electrode for the classical ESR and the liquid metal for the ESR LM were obtained from the same rough material by remelt- 
ing it in the electroslag crucible furnace. In the consumable electrode of $160 \mathrm{~mm}$ in diameter for the standard ESR, the measured sulphur content was of $0.026-0.028$ wt.\%.

Within the frame of accuracy, the close sulphur content of $0.025-$ 0.029 wt. $\%$ was obtained in the liquid metal before feeding it into the mould. The samples were cut from the finished ingots from the head, middle and bottom parts in the metal of which the sulphur content was determined; see Fig. 5 .

The same sulphur content obtained at the beginning of the remelting in the bottom parts of both ingots is a direct confirmation of a similar degree of development of physical-chemical interactions in the ESR and ESR LM. Therefore, despite a difference in the degree of surface development, the ESR LM provides the same degree of desulphurization as it occurs in classical ESR. A decrease of the temperature by 70-95 $\mathrm{K}$ for the metal fed into the melting space, did also not slow down the desulphurization process.

The obtained results testify that the main refining reactions between slag and metal occur on the contact surface of the slag and metal bath, but not in the film at the end of the electrode. An additional argument against the view that the film at the end of the electrode is the main place of refining is that the Archimedes force counteracts the removal of non-metallic inclusions in the slag. On the contrary, their assimilation by the slag from the metal bath surface occurs in the most favourable conditions.

A slightly higher degree of desulphurization in the ESR RM in the middle and head parts of the ingot results most likely from the additional action of slag which covered the liquid metal during storage in the crucible. For this reason, if it is necessary to increase the degree of refining in the process of ESR LM, it is possible to arrange additional processing of metal in the pouring device, or, e.g., a treatment with two slags having different compositions in the pouring device, crucible in our experiments, and in the mould.

Finally, a decrease of the temperature of slag and metal overheating in the ESR LM as compared to the classical ESR reduces the volume of the liquid metal bath. This (in turn) improves conditions for ingot formation and (as proven in practice) reduces the development of segregation processes, as well as allows the obtaining of a homogeneous metal composition and structure, which acts as a precondition for a high and stable properties. 


\section{Summary}

The numerical comparison of conditions for the heat-mass transfer processes in the slag-metal system during electroslag remelting with a consumable electrode and with liquid metal at the ESR LM leads to following conclusions.

(i) The temperature of metal fed into the melting space at the ESR LM is lower by 70 to $95 \mathrm{~K}$.

(ii) Due to the absence of a film at the end of the electrode and smaller surface of the drops and stream, the interaction surface at the ESR RM is approximately twice smaller than at the ESR.

(iii) Modelling the velocity in slag and heating of liquid metal drops according to the model that takes into account the flows in the drop volume have shown that, with increasing drop size, a deviation of their velocity from that predicted by Stokes' law for a solid sphere of the same diameter increases. For drops of 3 to $10 \mathrm{~mm}$ in size, it increases by 3 to $26 \%$, and the larger their size the higher is the increase of velocity of motion and the deviation rate according to Stokes' law.

(iv) The same level of desulphurization in the both processes despite the difference in the development of the contact surfaces of metal and slag is experimentally proven, which indicates to the main role of the metal bath in the removal of non-metallic inclusions. The absence of a film at the end of the electrode and the smaller surface size of the stream and drops in the ESR LM does not reduce degree of desulphurization, which evidences the completeness of reactions of metal interaction with slag and assimilation of non-metallic inclusions.

\section{REFERENCES}

1. B.E. Paton and B.I. Medovar, Electroslag Metal (Kiev: Naukova Dumka: 1981) (in Russian).

2. B.I. Medovar, A.K. Tsykulenko, and V.L. Shevtsov, Metallurgy of Electroslag Process (Kiev: Naukova Dumka: 1986) (in Russian).

3. I. Gibson, D. Rosen, and B. Stucker, Additive Manufacturing Technologies: $3 D$ Printing, Rapid Prototyping, and Direct Digital Manufacturing (New York: Springer-Verlag: 2015). https://doi.org/10.1007/978-1-4939-2113-3

4. W.J. Sames, F.A. List, S. Pannala, R.R. Dehoff, and S.S. Babu, Int. Mater. Rev., 61, No. 5: 315 (2016). https://doi.org/10.1080/09506608.2015.1116649.

5. R.J. Fruehan, O. Fortini, H.W. Paxtonand, and R. Brindle, Theoretical Minimum Energies to Produce Steel for Selected Conditions (Pittsburgh, PA: Carnegie Mellon University; Columbia, MD: Energetics, Inc.: 2000). https://doi.org/10.2172/769470

6. L.A. Lisova, A.P. Stovpchenko, L.B. Medovar, and V.L. Petrenko, Electrometallurgy Today, No. 2: 3 (2017) (in Ukrainian).

https://doi.org/10.15407/sem2017.02.01 
7. M.M. Klyuev and S.V. Wolkov, Ehlektroshlakovaya Pereplavka [Electroslag Remelting] (Moscow: Metallurgy: 1984) (in Russian).

8. B.I. Medovar, A.V. Chernets, L.B. Medovar, V.E. Shevchenko, V.P. Trypolskaya, B.B. Fedorowsky, Yu.V. Orlowsky, A.P. Beloglazov, and I.A. Lantsman, Problemy Spetsialnoy Ehlektrometallurgii [Advances in Special Electrometallurgy], No. 1: 7 (1995) (in Russian).

9. B.I. Medovar, A.V. Chernets, L.B. Medovar, B.B. Fedorowsky, V.E. Shevchenko, I.A. Lantsman, A.K. Tsykulenko, and V.I. Us, Problemy Spetsialnoy Ehlektrometallurgii [Advances in Special Electrometallurgy], No. 1: 3 (1997) (in Russian).

10. B.I. Medovar, L.B. Medovar, V.Ya. Sayenko, and A.V. Chernets, Problemy Spetsialnoy Ehlektrometallurgii [Advances in Special Electrometallurgy], No. 3: 3 (1999) (in Russian).

11. L.B. Medovar, A.K. Tsykulenko, A.V. Chernets, B.B. Fedorowsky, V.E. Shevchenko, I.A. Lantsman, Ts.F. Grabowsky, V.I. Us, and V.L. Petrenko, Problemy Spetsialnoy Ehlektrometallurgii [Advances in Special Electrometallurgy], No. 4: 7 (2000) (in Russian).

12. L.B. Medovar, A.P. Stovpchenko, A.N. Golovachev, and B.B. Fedorovsky, Electrometallurgy Today, No. 3: 12 (2013) (in Russian).

13. B.I. Medovar, V.L. Shevtsov, and V.L. Martin, Ehlektroshlakovaya Tigel'naya Plavka i Razlivka Metalla [Electroslag Crucible Melting and Pouring of Metal] (Kiev: Naukova Dumka: 1988) (in Russian).

14. I.V. Chumanov and D.A. Pyatygin, Izvestiya VUZov. Chernaya Metallurgiya, No. 3: 22 (2006) (in Russian).

15. K. Kajikawa, A. Mitchell, and K.M. Kelkar, Proc. IFM 2014 (Tokyo: Japan Steel Castings and Forgings Association: 2014), p. 124.

16. B. Hernandez-Morales and A. Mitchell, Ironmaking \& Steelmaking, 26, No. 6: 423 (1999). https://doi.org/10.1179/030192399677275

17. A. Kharicha, E. Karimi-Sibaki, M. Wu, A. Ludwig, and J. Bohacek, Steel Research Intern., 89, No. 1: 17001002018. https://doi.org/10.1002/srin.201700100

18. W. Fang, J. Baleta, Q. Wang, and B. Li. Open Physics, 17, No. 1: 743 (2019). https://doi.org/10.1515/phys-2019-0078

19. A. Mitchell and S. Joshi, Metallurgical Transactions, 4: 631 (1973). https://doi.org/10.1007/BF02643068

20. M.M. Klyuev and A.F. Kablukovsky, Metallurgiya Ehlektroshlakovoy Pereplavki [Metallurgy of Electroslag Remelting] (Moscow: Metallurgiya: 1969) (in Russian).

21. G.I. Zhmoidin, Vosstanovlenie i Rafinirovanie Zheleza [Recovery and Refining of Iron] (Moscow: Nauka: 1969) (in Russian).

22. A. Kharicha, A. Ludwig, M. Wu, H. Scholz, W. Schtzenhfer, G. Reiter, R. Tanzer, A. Mackenbrock, O. Köser, A. Carosi, R. Sorci, and F. Arcobello-Varlese, Integrated Simulation of Advanced Protective Gas Electroslag Remelting for the Production of High-Quality Steels (ISA-PESR) (Luxembourg: Publications Office of the European Union, Contract No. RFSR-CT-2004-00027: 2009).

23. I. Garevskikh, Yu. Shulte, V. Maximenko, and B. Speransky, Stal', No. 1: 39 (1962) (in Russian).

24. A. Kharicha, A. Ludwig, and M. Wu, EPD Congress 2011 (Eds. S.N. Monteiro, D.E. Verhulst, P.N. Anyalebechi, and J.A. Pomykala) (Pittsburgh: The Minerals, Metals \& Materials Society: 2011).

https://doi.org/10.1002/9781118495285.ch84 
25. H. Wang, Y. Zhong, Q. Li, Y. Fang, W. Ren, Z. Lei, and Z. Ren, ISIJ International, 56, No. 2: 255 (2016).

https://doi.org/10.2355/isijinternational.ISIJINT-2015-581

26. R. Clift, J.R. Grace, and M.E. Weber, Bubbles, Drops, and Particles (New YorkLondon: Academic Press: 1978).

27. E.E. Michaelides, Particles, Bubbles \& Drops: Their Motion, Heat and Mass Transfer (World Scientific: 2006). https://doi.org/10.1142/6018

28. C. Crowe, J. Schwarzkopf, M. Sommerfeld, and Y. Tsuji, Multiphase Flows with Droplets and Particles (Boca Raton: CRC Press: 2012). https://doi.org/10.1201/b11103

29. S. Middleman, Modeling Axisymmetric Flows: Dynamics of Films, Jets, and Drops (Academic Press: 1995).

30. A.F. Yang, A. Karasev, and P.G. Jonsson, ISIJ International, 55, No. 3: 570 (2015). https://doi.org/10.2355/isijinternational.55.570

31. P.K. Iwamasa and R.J. Fruehan, ISIJ International, 36, No. 11: 1319 (1996). https://doi.org/10.2355/isijinternational.36.1319

32. V.G. Yefimova, Metall i Lit'ye Ukrainy, No. 1: 248 (2014) (in Russian).

33. G. Brooks, Y. Pan, Subagyo, and K. Coley Metall. Mater. Trans. B, 36: 525 (2005). 33 https://doi.org/10.1007/s11663-005-0044-x

34. Subagyo and G. Brooks, ISIJ International, 42, No. 10: 1182 (2002). https://doi.org/10.2355/isijinternational.42.1182

35. C. Yang and Z. Mao, Numerical Simulation of Multiphase Reactors with Continuous Liquid Phase (Academic Press: 2014).

36. V.G. Levich, Fiziko-Khimicheskaya Gidrodinamika [Physical-Chemical Hydrodynamics] (Moscow: PhysMatGiz: 1962 (in Russian).

37. S.L. Soo, Fluid Dynamics of Multiphase Systems (Waltham, Mass., Blaisdell Pub. Co.: 1967).

38. B.I. Brounshtein and V.V. Shchegolev, Gidrodinamika, Masso- i Teploobmen $v$ Kolonnykh Apparatakh [Hydrodynamics of Mass and Heat Exchange in Column Apparatus] (Leningrad: Khimiya: 1988).

39. M.M. Kjuyev and Yu.M. Mironov, Stal', 6: 511 (1967) (in Russian).

40. B.I. Brounstein and G.A. Fishbain, Gidrodinamika Masso- $i$ Teploonmena $v$ Dispersnykh Sistemakh [Hydrodynamics of Mass and Heat Exchange in Disperse Systems] (Leningrad: Khimiya: 1977) (in Russian).

41. W.E. Ranz and W.R. Marshall, Jr., Chem. Eng. Prog., 48, No. 3: 141 (1952); ibid. 173 (1952).

Received 02.07.2020;

in final version, 09.10.2020 
Г.П. Стовпченко ${ }^{1,2}$, А.В. Сибір ${ }^{2,3}$,

Г.О. Полішко ${ }^{1}$, Л.Б. Медовар ${ }^{1,2}$, Я.В. Гусєв ${ }^{1}$

${ }^{1}$ Інститут електрозварювання ім. Є.О. Патона НАН України, вул. Казимира Малевича, 11, 03150 Київ, Україна

${ }^{2}$ Інжинірингова компанія «ЕЛМЕТ-РОЛ», а/с 259, 03150 Київ, Україна

${ }^{3}$ Національна металургійна академія України, пр. Гагаріна, 4, 49600 Дніпро, Україна

\section{МАСООБМІН ПРИ ЕЛЕКТРОШЛАКОВИХ ПРОЦЕСАХ} З ВИТРАТНИМ ЕЛЕКТРОДОМ І З РІДКИМ МЕТАЛОМ

Експериментальне та розрахункове порівняння масообмінних процесів при електрошлаковому переплаві з витратним електродом (ЕШП) і рідким металом (ЕШП PM) показало їхню однакову рафінувальну здатність, попри менші в останньому випадку (вдвічі) поверхню контакту шлак-метал і перегрів металу (на 70-95 К). Встановлено, що крапля рідкого металу в рідкому шлаку рухається швидше, ніж тверда частинка такого ж діаметру за рахунок ефекту руху металу всередині краплі. В порівнянних умовах експериментально підтверджено, що десульфурація при ЕШП відбувається в основному на поверхні контакту шлакової та металевої ванн, а не у плівці рідкого металу на торці витратного електроду.

Ключові слова: електрошлаковий переплав з витратним електродом, критерії подібности, турбулентність, струмінь, десульфурація. 